\title{
Sequential HBV Treatment With Tenofovir Alafenamide for Patients With Chronic Hepatitis B: Week 96 Results From a Real-world, Multicenter Cohort Study
}

Eiichi Ogawa ( $\nabla$ eogawa@gim.med.kyushu-u.ac.jp )

Kyushu University Hospital https://orcid.org/0000-0002-5082-3967

Makoto Nakamuta

Kyushu Medical Center

Toshimasa Koyanagi

Fukuoka City Hospital: Fukuoka Shimin Byoin

Aritsune Ooho

Steele Memorial Yawata Hospital

Norihiro Furusyo

Taihaku Avenue Clinic

Eiji Kajiwara

Kajiwara Clinic

Kazufumi Dohmen

Chihaya Hospital

Akira Kawano

Kitakyushu Municipal Medical Center: Kitakyushu Shiritsu Iryo Center

Takeaki Satoh

Kokura Medical Center

Kazuhiro Takahashi

Hamanomachi Hospital

Koichi Azuma

Kyushu Central Hospital

Nobuyuki Yamashita

Shin-Kokura Hospital

Naoki Yamashita

Kyushu Medical Center

Rie Sugimoto

Kyushu Cancer Center

Hiromasa Amagase

Amagase Clinic 


\section{Masami Kuniyoshi}

Kyushu Rosai Hospital: Kyushu Rosai Byoin

\section{Yasunori Ichiki}

JCHO Kyushu Hospital

\section{Chie Morita}

Railway Kyushu Memorial Hospital

\section{Shinji Shimoda}

Kyushu University: Kyushu Daigaku

\section{Hideyuki Nomura}

Haradoi Hospital

\section{Jun Hayashi}

Haradoi Hospital

\section{Research Article}

Keywords: Hepatitis B virus, Tenofovir alafenamide, Entecavir, Tenofovir disoproxil fumarate, Sequential therapy

Posted Date: March 11th, 2021

DOl: https://doi.org/10.21203/rs.3.rs-268836/v1

License: (a) This work is licensed under a Creative Commons Attribution 4.0 International License. Read Full License

Version of Record: A version of this preprint was published at Hepatology International on January 25th, 2022. See the published version at https://doi.org/10.1007/s12072-021-10295-3. 


\section{Abstract}

Background and Aims

Outcome data of sequential hepatitis B virus treatment with tenofovir alafenamide (TAF) are limited. We aimed to assess the effectiveness and renal safety of TAF in chronic hepatitis $B(C H B)$ patients who were previously treated with entecavir (ETV), tenofovir disoproxil fumarate (TDF), or nucleos(t)ide analog (NA) combination.

\section{Methods}

This multicenter, retrospective, cohort study included 458 consecutive $\mathrm{CHB}$ patients who switched to TAF monotherapy after at least two years of treatment with another NA. The longitudinal virological/laboratory responses were evaluated up to 96 weeks after switchover. Chronic kidney disease (CKD) was defined as an estimated glomerular filtration rate (eGFR) $<60 \mathrm{~mL} / \mathrm{min} / 1.73 \mathrm{~m}^{2}$.

Results

The proportions of HBV DNA suppression (HBV DNA<20 IU/mL) at week 96 were $99.0 \%, 97.8 \%$, and $98.4 \%$ in the prior ETV $(n=198)$, TDF $(n=137)$, and NA combination $(n=123)$ groups, respectively. Almost all patients with HBV DNA of 20-2000 IU/mL at baseline achieved HBV DNA suppression at week 96 . On multivariable generalized estimated equation (GEE) analysis, a low quantitative hepatitis surface antigen (qHBsAg) level at baseline was associated with a lower follow-up qHBsAg level (coefficient 0.81, $P<0.001)$. The eGFR showed greater improvement in patients with CKD compared to those with non-CKD according to the multivariable GEE analysis (coefficient 21.7, $P<0.001$ ). However, the increase of eGFR reached a peak between weeks 24 and 48 .

\section{Conclusions}

Based on this longitudinal data analysis up to 96 weeks, sequential NA therapy with a switch to TAF is a good option to better achieve high viral suppression and renal safety.

\section{Introduction}

Chronic hepatitis $\mathrm{B}(\mathrm{CHB})$ remains one of the leading causes of cirrhosis, hepatocellular carcinoma (HCC), and liver-related mortality worldwide [1, 2]. Antiviral treatment with potent nucleos(t)ide analogues (NA) such as entecavir (ETV), tenofovir disoproxil fumarate (TDF), and tenofovir alafenamide fumarate (TAF) is widespread, and they have been recommended as first-line oral agents that can reduce the risk of HCC development and liver-related complications [3-5]. Hepatitis B surface antigen (HBsAg) seroclearance is currently regarded as the functional cure because this is uncommon among treated patients [6, 7], thus for almost all patients lifelong NA treatment is necessary. 
TAF is the newest NA drug approved for use in hepatitis B virus (HBV) treatment in Japan, at the end of 2016.

It is a prodrug of tenofovir, a nucleotide analogue that inhibits reverse transcription of both HBV and human immunodeficiency virus (HIV) [8]. Other first-line drugs with ETV and TDF were approved in 2005 and 2008, respectively, and good virological efficacy has been provided [9-11], although impaired kidney function and decreased bone mineral density (BMD) have been reported in long-term TDF treatment [12, 13]. Therefore, the majority of $\mathrm{CHB}$ patients continue to be treated with ETV or TDF. According to ongoing phase III trials of the efficacy and safety of TAF versus TDF for CHB patients [14-16], TAF has been shown to be virologically effective and well tolerated, with improved renal and bone safety for patients switching from TDF. Unfortunately, data, including real-world data, on the effectiveness and safety of TAF following switching from ETV or NA combinations is lacking.

We recently published real-world data on the effectiveness and renal safety of TAF for patients who had previously been treated with ETV or NA combinations [17]. Our results showed that the rate of HBV DNA suppression significantly increased and that a continued reduction of the quantitative HBsAg (qHBsAg) level was noted at week 48. Moreover, the estimated glomerular filtration rate (eGFR) was significantly improved in patients with chronic kidney disease (CKD) who were treated with a nucleotide analogue. Although advantages from the switchover were elucidated, the length of time for follow-up post switch was somewhat short, less than one year, thus, the purpose of this study was to examine virological, biochemical, and renal outcomes up to 96 weeks in a multicenter, real-world cohort of CHB patients who have switched to TAF from ETV, TDF, or an NA combination.

\section{Patients And Methods}

\section{Patients}

The Kyushu University Liver Disease Study (KULDS) Group consists of hepatologists from Kyushu University Hospital and its affiliated hospitals located in the northern Kyushu area of Japan. This multicenter, retrospective, observational cohort study consisted of consecutive patients from March 2017 until December 2018 who switched to a fixed-dose of TAF, 25mg orally once daily (Vemlidy; Gilead Sciences K.K., Tokyo, Japan).

Eligible patients were (1) aged 18 years and older with confirmed chronic HBV infection, and (2) NA treatment switching to TAF monotherapy from an at least two-year course of ETV, TDF, or an NA combination of lamivudine (LAM)/adeforvir (ADF), LAM/TDF, ETV/ADF, or ETV/TDF. Exclusion criteria included (1) duration of follow-up under two years: (2) viable HCC within three months before TAF initiation by imaging examination such as abdominal ultrasound, computed tomography, or magnetic resonance imaging; (3) positivity for antibody to HIV or positivity for hepatitis C antibody; (4) terminal illness; and (5) insufficient medical records for primary endpoints and objectives. 
The study was conducted in accordance with the ethical principles of the Declaration of Helsinki and the STROBE statement.

It was approved by the Ethics Committees of Kyushu University Hospital and each study site and is registered as a clinical study on the University Hospital Medical Information Network (ID 000034696).

\section{Laboratory, and virological assessments}

All patients were followed every 8-12 weeks during TAF treatment.

Laboratory assessments included hematological analysis, serum biochemistry tests, and urinalysis, including measures of renal function. The eGFR was calculated with the following formulas [18]; for men eGFR $\left(\mathrm{mL} / \mathrm{min} / 1.73 \mathrm{~m}^{2}\right)=194 \times$ serum creatinine level ${ }^{-1.094} \times$ age $^{-0.287}$ and for women eGFR $=194 \times$

$\mathrm{SCr}^{-1.094} \times$ age $^{-0.287} \times 0.739$. As a renal safety endpoint, we defined CKD and the lower limit of the serum phosphorus level as an eGFR $<60 \mathrm{~mL} / \mathrm{min} / 1.73 \mathrm{~m}^{2}$ and serum phosphorus level $<2.5 \mathrm{mg} / \mathrm{dL}$, respectively. Liver cirrhosis was defined by liver biopsy demonstrating a METAVIR F4 score, transient elastography (FibroScan ${ }^{\circledR}$; Echosens, Paris, France) greater than $12.0 \mathrm{kPa}$ [19], or ultrasound examination with signs of cirrhosis based on nodularity, portal velocity, liver size, caudate hypertrophy, echogenicity, portal vein diameter, and spleen size. These assessments were performed within three months before the initiation of TAF treatment.

\section{Primary and secondary endpoints}

The primary endpoint was the proportion of patients with HBV DNA suppression (less than $20 \mathrm{lU} / \mathrm{mL}$, the lower limit of quantitation) as determined by real-time reverse transcriptase PCR assay (COBAS TaqMan HBV assay, Version 2.0) (Roche Molecular Diagnostics, Tokyo, Japan) at week 96 after switching to TAF. Key prespecified secondary endpoints were the longitudinal change of alanine aminotransferase (ALT), qHBsAg level, and eGFR. A patient was determined to have ALT normalization if ALT was less than 35 $\mathrm{U} / \mathrm{L}$ for men or $25 \mathrm{U} / \mathrm{L}$ for women, according to the American Association for the Study of Liver Diseases (AASLD) normal range [3]. Moreover, we calculated complete response rates with both HBV DNA suppression and ALT normalization.

\section{Statistical analysis}

Statistical analyses were conducted using SPSS Statistics version 25.0 (IBM SPSS Inc, Chicago, IL, USA). Baseline continuous data are expressed as median (first-third quartile) or mean ( \pm standard deviation) and categorical variables are reported as frequencies and percentages. Trends for continuous variables were assessed using the repeated measures ANOVA test. Univariate analyses were done using the Chisquare, Student's $t$, or Mann-Whitney $\mathrm{U}$ test, as appropriate. We used the multivariable generalized estimating equation (GEE) model adjusted for age, sex, body mass index (BMI), cirrhosis, hypertension, diabetes mellitus, and previous NA regimen to estimate coefficients associated with baseline parameters or factors to changes in ALT, qHBsAg level, and eGFR. The results are expressed as coefficients and their $95 \%$ confidence interval $(\mathrm{Cl})$. A $P$ value less than 0.05 was regarded as statistically significant in all analyses. 


\section{Results}

\section{Patient characteristics}

A total of 478 patients who switched to TAF were identified during the study period.

Twenty were excluded in accordance with the criteria, leaving the data of 458 available for analysis.

Of the eligible patients, 198 (43.2\%) received ETV, 137 (29.9\%) TDF, and 123 (26.9\%) an NA combination before switching to TAF. Demographic and baseline characteristics according to the previous NA treatment are shown in Table 1. Median treatment durations of the previous drug for the ETV, TDF, and NA combination groups were $7.0,4.5$, and 4.3 years, respectively. 
Table 1

Baseline characteristics according to the previous nucleos(t)ide analog (NA) treatment

\begin{tabular}{|c|c|c|c|}
\hline Previous NA regimen & Entecavir & $\begin{array}{l}\text { Tenofovir disoproxil } \\
\text { fumarate }\end{array}$ & $\begin{array}{l}\text { NA } \\
\text { combination }\end{array}$ \\
\hline Number & 198 & 137 & 123 \\
\hline Age & $61(50-69)$ & $51(43-66)$ & $61(53-68)$ \\
\hline range & $26-90$ & $29-79$ & $33-84$ \\
\hline Male & $124(62.6)$ & $78(56.9)$ & $81(65.9)$ \\
\hline Body mass index $\left(\mathrm{kg} / \mathrm{m}^{2}\right)$ & $\begin{array}{l}22.4(20.3- \\
24.3)\end{array}$ & $22.3(20.5-24.9)$ & $\begin{array}{l}22.9(20.9- \\
25.2)\end{array}$ \\
\hline Cirrhosis & $27(13.6)$ & $20(14.6)$ & $23(18.7)$ \\
\hline History of HCC & $19(9.6)$ & $16(11.7)$ & $22(17.9)$ \\
\hline Hypertension & $58(29.3)$ & $14(10.2)$ & $25(20.3)$ \\
\hline Diabetes & $26(13.1)$ & $14(10.2)$ & $16(13.0)$ \\
\hline Albumin $(g / L)$ & $43(41-45)$ & $43(41-45)$ & $44(41-46)$ \\
\hline Total bilirubin (mg/dL) & $0.8(0.5-1.1)$ & $0.7(0.5-1.0)$ & $0.7(0.4-1.0)$ \\
\hline AST (U/L) & $24(19-29)$ & $25(22-32)$ & $24(20-30)$ \\
\hline ALT (U/L) & $20(14-27)$ & $24(18-34)$ & $20(16-31)$ \\
\hline gGTP (U/L) & $24(17-44)$ & $21(15-40)$ & $21(15-42)$ \\
\hline eGFR (mL/min/1.73m²) & $71(61-82)$ & $74(62-85)$ & $69(55-81)$ \\
\hline $30-60$ & $44(22.2)$ & $29(21.2)$ & $34(27.6)$ \\
\hline $15-<30$ & $2(1.0)$ & $2(1.5)$ & $3(2.4)$ \\
\hline Phosphorus (mg/dL) & $3.3(3.0-3.6)$ & $3.3(2.8-3.7)$ & $3.0(2.6-3.5)$ \\
\hline $\operatorname{AFP}(\mathrm{ng} / \mathrm{mL})$ & $2.9(2.0-3.4)$ & $3.0(2.2-4.4)$ & $3.0(2.1-3.7)$ \\
\hline Platelet count $\left(10^{3} / \mu \mathrm{L}\right)$ & $\begin{array}{l}178(146- \\
218)\end{array}$ & $184(144-235)$ & $183(139-221)$ \\
\hline HBeAg positive & $28(14.1)$ & $31(22.6)$ & $27(22.0)$ \\
\hline
\end{tabular}

Data are $\mathrm{n}(\%)$ or median (first-third quartile).

HCC, hepatocellular carcinoma; AST, aspartate aminotransferase; ALT, alanine aminotransferase; gGTP, gamma-glutamyl transpeptidase; eGFR, estimated glomerular filtration rate; AFP, alphafetoprotein; HBeAg, hepatitis B e antigen; HBV, hepatitis B virus; LAM, lamivudine; ADV, adefovir; ETV, entecavir; TDF, tenofovir disoproxil fumarate. 


\begin{tabular}{|llll|}
\hline Previous NA regimen & Entecavir & $\begin{array}{l}\text { Tenofovir disoproxil } \\
\text { fumarate }\end{array}$ & \multicolumn{1}{c|}{$\begin{array}{l}\text { NA } \\
\text { combination }\end{array}$} \\
\hline HBV DNA (IU/mL) & $152(76.8)$ & $130(94.9)$ & $113(91.9)$ \\
$<20$ + or negative & $34(17.2)$ & $7(5.1)$ & $10(8.1)$ \\
$20-2,000$ & $12(6.1)$ & 0 & 0 \\
$>2,000$ & & & $4.3(3.2-9.2)$ \\
$\begin{array}{l}\text { Previous NA treatment duration } \\
\text { (year) }\end{array}$ & $5.0(4.3-7.4)$ & $3.2(2.6-3.5)$ & $44(35.8)$ \\
\hline $\begin{array}{l}\text { Previous NAs combination } \\
\text { LAM + ADV }\end{array}$ & & $39(31.7)$ \\
LAM + TDF & & 3 (2.4) \\
ETV + ADV & & 37 (30.1) \\
ETV + TDF & & \\
\hline \begin{tabular}{l} 
Data are n (\%) or median (first-third quartile). \\
\hline $\begin{array}{l}\text { HCC, hepatocellular carcinoma; AST, aspartate aminotransferase; ALT, alanine aminotransferase; } \\
\text { gGTP, gamma-glutamyl transpeptidase; eGFR, estimated glomerular filtration rate; AFP, alpha- }\end{array}$ \\
fetoprotein; HBeAg, hepatitis B e antigen; HBV, hepatitis B virus; LAM, lamivudine; ADV, adefovir; ETV, \\
entecavir; TDF, tenofovir disoproxil fumarate.
\end{tabular} \\
\hline
\end{tabular}

In the prior ETV group, the median age was 61, 124 (62.6\%) were male, 27 (13.6\%) had compensated cirrhosis, and 28 (14.1\%) were hepatitis B e antigen (HBeAg)-positive at baseline. Approximately $23 \%$ had HBV DNA more than $20 \mathrm{IU} / \mathrm{mL}$. In the prior TDF group, the median age was 51, 78 (56.9\%) were male, 20 (14.6\%) had compensated cirrhosis, and 31 (22.6\%) were HBeAg-positive at baseline. Unlike the prior ETV group, almost all (94.9\%) had HBV DNA less than $20 \mathrm{IU} / \mathrm{mL}$. In the prior NA combination group, the median age was 61, 81 (65.9\%) were male, $23(18.7 \%)$ had compensated cirrhosis, and $27(22.0 \%)$ were HBeAg-positive at baseline. Similar to the prior TDF group, almost all (91.9\%) had HBV DNA less than 20 $\mathrm{IU} / \mathrm{mL}$. Furthermore, in the prior TDF and NA combination groups, none of the patients had uncontrolled HBV DNA (>2,000 IU/mL).

\section{Virological and biochemical responses 96 weeks after switching to TAF}

The proportions of HBV DNA suppression at week 96 after switchover were 99.0\% (196/198), 97.8\% (134/137), and $98.4 \%(121 / 123)$ in the prior ETV, TDF, and NA combination groups, respectively. Of the 46 patients who had prior ETV with HBV DNA of $20-2000 \mathrm{lU} / \mathrm{mL}$ at baseline, most achieved HBV DNA suppression from the early stage of TAF treatment, and at week 96 the proportion was $95.7 \%(42 / 44)$ (Table 2). Regardless of the prior treatment regimen, none experienced HBV breakthrough during the follow-up period. In contrast, the achievement rates of HBeAg loss for patients HBeAg-positive at baseline 
remained low; under $30 \%$ in all prior treatment groups (Table 2). Even though patients had a low-titer of HBeAg ( $<10$ S/CO) at baseline, only 35-40\% had achieved HBeAg loss at week 96. 
Table 2

HBeAg loss and HBV DNA suppression after switching to tenofovir alafenamide

\begin{tabular}{|c|c|c|c|c|c|c|}
\hline & $\begin{array}{l}\mathrm{HBeAg} \\
\text { titer at } \\
\text { baseline } \\
\text { (S/CO) }\end{array}$ & $\begin{array}{l}\text { HBeAg } \\
\text { loss at } \\
\text { week } \\
48\end{array}$ & $\begin{array}{l}\text { HBeAg } \\
\text { loss at } \\
\text { week } \\
96\end{array}$ & $\begin{array}{l}\text { HBV DNA } \\
\text { level at } \\
\text { baseline } \\
\text { (IU/mL) }\end{array}$ & $\begin{array}{l}\text { HBV DNA } \\
\text { suppression } \\
\text { at week } 48\end{array}$ & $\begin{array}{l}\text { HBV DNA } \\
\text { suppression } \\
\text { at week } 96\end{array}$ \\
\hline \multicolumn{7}{|l|}{ Previous ETV } \\
\hline \multirow{5}{*}{$\begin{array}{l}\text { HBeAg-positive } \\
\text { at baseline }(n= \\
28)\end{array}$} & \multirow{2}{*}{$\begin{array}{l}1-<10 \\
10-<100\end{array}$} & $\begin{array}{l}3 / 8 \\
(375)\end{array}$ & \multirow{2}{*}{$\begin{array}{l}3 / 8 \\
(37.5)\end{array}$} & & & \\
\hline & & & & & & \\
\hline & $>100$ & $\begin{array}{l}1 / 5 \\
(20.0)\end{array}$ & $\begin{array}{l}2 / 5 \\
(40.0)\end{array}$ & & & \\
\hline & \multirow[t]{2}{*}{ Unknown } & $\begin{array}{l}1 / 10 \\
(10.0)\end{array}$ & $\begin{array}{l}1 / 10 \\
(10.0)\end{array}$ & & & \\
\hline & & $\begin{array}{l}1 / 5 \\
(20.0)\end{array}$ & $\begin{array}{l}2 / 5 \\
(40.0)\end{array}$ & & & \\
\hline \multirow{2}{*}{$\begin{array}{l}\text { HBV DNA- } \\
\text { positive at } \\
\text { baseline }(n=46)\end{array}$} & & & & \multirow{2}{*}{$\begin{array}{l}20-2000 \\
>2000\end{array}$} & $\begin{array}{l}33 / 34 \\
(97.1)\end{array}$ & $\begin{array}{l}33 / 34 \\
(97.1)\end{array}$ \\
\hline & & & & & $9 / 12(75.0)$ & $\begin{array}{l}11 / 12 \\
(91.7)\end{array}$ \\
\hline $\begin{array}{l}\text { HBV DNA } \\
\text { suppression at } \\
\text { baseline ( } \mathrm{n}= \\
152)\end{array}$ & & & & $<20$ & $\begin{array}{l}152 / 152 \\
(100)\end{array}$ & $\begin{array}{l}152 / 152 \\
(100)\end{array}$ \\
\hline \multicolumn{7}{|l|}{ Previous TDF } \\
\hline \multirow{5}{*}{$\begin{array}{l}\text { HBeAg-positive } \\
\text { at baseline }(n= \\
\text { 31) }\end{array}$} & \multirow{2}{*}{$\begin{array}{l}1-<10 \\
10-<100\end{array}$} & \multirow{2}{*}{$\begin{array}{l}5 / 18 \\
(27.8)\end{array}$} & \multirow{2}{*}{$\begin{array}{l}7 / 18 \\
(38.9)\end{array}$} & & & \\
\hline & & & & & & \\
\hline & $>100$ & $\begin{array}{l}1 / 6 \\
(16.7)\end{array}$ & $\begin{array}{l}1 / 6 \\
(16.7)\end{array}$ & & & \\
\hline & \multirow[t]{2}{*}{ Unknown } & $\begin{array}{l}1 / 7 \\
(14.3)\end{array}$ & $\begin{array}{l}1 / 7 \\
(14.3)\end{array}$ & & & \\
\hline & & - & - & & & \\
\hline \multirow{2}{*}{$\begin{array}{l}\text { HBV DNA- } \\
\text { positive at } \\
\text { baseline }(n=7)\end{array}$} & & & & $20-2000$ & $3 / 7$ (42.9) & 5 / 7 (71.4) \\
\hline & & & & $>2000$ & - & - \\
\hline $\begin{array}{l}\text { HBV DNA } \\
\text { suppression at } \\
\text { baseline }(n= \\
129)\end{array}$ & & & & $<20$ & $\begin{array}{l}129 / 129 \\
(100)\end{array}$ & $\begin{array}{l}129 / 129 \\
(100)\end{array}$ \\
\hline \multicolumn{7}{|l|}{ Data are $\mathrm{n}(\%)$} \\
\hline $\begin{array}{l}\text { HBeAg, hepatitis } \\
\text { NA, nucleos }(t) \text { ide }\end{array}$ & $\begin{array}{l}\text { antigen; } \vdash \\
\text { alog. }\end{array}$ & hepati & virus; & entecavir; T & enofovir diso & xil fumarate; \\
\hline
\end{tabular}




\begin{tabular}{|c|c|c|c|c|c|c|}
\hline & $\begin{array}{l}\mathrm{HBeAg} \\
\text { titer at } \\
\text { baseline } \\
(\mathrm{S} / \mathrm{CO})\end{array}$ & $\begin{array}{l}\text { HBeAg } \\
\text { loss at } \\
\text { week } \\
48\end{array}$ & $\begin{array}{l}\text { HBeAg } \\
\text { loss at } \\
\text { week } \\
96\end{array}$ & $\begin{array}{l}\text { HBV DNA } \\
\text { level at } \\
\text { baseline } \\
\text { (IU/mL) }\end{array}$ & $\begin{array}{l}\text { HBV DNA } \\
\text { suppression } \\
\text { at week } 48\end{array}$ & $\begin{array}{l}\text { HBV DNA } \\
\text { suppression } \\
\text { at week } 96\end{array}$ \\
\hline \multicolumn{7}{|l|}{$\begin{array}{l}\text { Previous NA } \\
\text { combination }\end{array}$} \\
\hline \multirow{5}{*}{$\begin{array}{l}\text { HBeAg-positive } \\
\text { at baseline }(n= \\
27)\end{array}$} & \multirow{3}{*}{$\begin{array}{l}1-<10 \\
10-<100 \\
>100\end{array}$} & $\begin{array}{l}3 / 11 \\
(30.0)\end{array}$ & \multirow{2}{*}{$\begin{array}{l}4 / 11 \\
(36.4)\end{array}$} & & & \\
\hline & & & & & & \\
\hline & & $(12.5)$ & $(12.5)$ & & & \\
\hline & \multirow[t]{2}{*}{ Unknown } & $0 / 7$ & $0 / 7$ & & & \\
\hline & & $0 / 1$ & $0 / 1$ & & & \\
\hline \multirow{2}{*}{$\begin{array}{l}\text { HBV DNA- } \\
\text { positive at } \\
\text { baseline }(n=10)\end{array}$} & & & & $20-2000$ & 7 / 10 (70.0) & $8 / 10(80.0)$ \\
\hline & & & & $>2000$ & - & - \\
\hline $\begin{array}{l}\text { HBV DNA } \\
\text { suppression at } \\
\text { baseline }(n= \\
113)\end{array}$ & & & & $<20$ & $\begin{array}{l}113 / 113 \\
(100)\end{array}$ & $\begin{array}{l}113 / 113 \\
(100)\end{array}$ \\
\hline \multicolumn{7}{|l|}{ Data are $\mathrm{n}(\%)$} \\
\hline $\begin{array}{l}\text { HBeAg, hepatitis } \\
\text { NA, nucleos }(\mathrm{t}) \text { ide }\end{array}$ & $\begin{array}{l}\text { antigen; } \vdash \\
\text { alog. }\end{array}$ & hepatiti & virus; & entecavir; & enofovir diso & xil fumarate; \\
\hline
\end{tabular}

The longitudinal ALT levels after switching to TAF are shown in Figs. 1-3 according to the prior NA regimen. Approximately $80 \%$ with prior ETV or an NA combination had normal ALT at baseline when using the $35 / 25 \mathrm{U} / \mathrm{L}$ cutoff of the AASLD guidelines. This showed no significant trend in the longitudinal levels, although the rates of ALT normalization slightly improved, from $82.3-90.4 \%$ and $78.0-83.7 \%$ in the prior ETV and NA combination groups, respectively. In contrast, the prior TDF group, in which the proportion of ALT normalization at baseline was relatively low $(71.5 \%)$, achieved a significant increase in the rate of ALT normalization (86.1\%) $(P<0.05)$. The proportions of complete response (both ALT normalization and HBV DNA suppression) at week 96 were $89.4 \%, 85.4 \%$, and $82.9 \%$ in the prior ETV, TDF, and NA combination groups, respectively (Supplementary Table 1). There were significant decreases in the qHBsAg level across all time points, irrespective of prior NA regimen (all $P<0.001$ ). Only seven patients $(1.5 \%)$ achieved HBsAg loss during the follow-up period.

Analysis of the longitudinal eGFR and serum phosphorus level, Figs. 1-3, found no significant trend in patients who switched from ETV to TAF. In contrast, the eGFR of patients with CKD who switched from TDF or an NA combination improved from the early stage. The increase of eGFR reached a peak between weeks 24 and 48, then decreased slightly over time. 


\section{Factors associated with the changes of ALT, qHBsAg level, and eGFR}

Results of our analysis of the factors associated with the changes in ALT, qHBsAg level, and eGFR at 96 weeks after switching to TAF are shown in Table 3. After adjusting for age, sex, BMI, cirrhosis, diabetes mellitus, and prior NA regimen, $\mathrm{BMI}$ (coefficient $1.69,95 \% \mathrm{Cl} 0.89-2.49, \mathrm{P}<0.001$ ) and cirrhosis (coefficient $4.03,95 \% \mathrm{Cl} 0.32-7.74, \mathrm{P}=0.033$ ) were associated with a longitudinal change in the ALT level. After adjusting for age, sex, cirrhosis, baseline HBeAg, baseline qHBsAg level, and prior NA regimen, age (coefficient - 7.75, 95\% Cl -14.3- -1.24, $\mathrm{P}=0.020$ ) and baseline qHBsAg level (coefficient 0.81, 95\% $\mathrm{Cl} 0.74-$ $0.88, P<0.001$ ) were associated with a longitudinal change in the qHBsAg level. Lastly, after adjusting for age, sex, BMI, cirrhosis, diabetes mellitus, hypertension, baseline eGFR, and prior NA regimen, age (coefficient $-0.48,95 \% \mathrm{Cl}-0.60--0.36, \mathrm{P}=0.020$ ) and baseline eGFR $<60$ (coefficient $21.7,95 \% \mathrm{Cl} 19.2-$ $24.1, \mathrm{P}<0.001)$ were associated with a longitudinal change in eGFR. 
Table 3

Generalized estimated equation analysis for estimated predictors of changes in ALT, qHBsAg, and eGFR levels after switching to tenofovir alafenamide

\begin{tabular}{|c|c|c|}
\hline & ALT & \\
\hline Characteristics & Coefficient $(95 \% \mathrm{Cl})$ & P-value \\
\hline Age (year) & $-0.11(-0.47-0.25)$ & 0.21 \\
\hline Male & $1.69(-3.13-6.51)$ & 0.49 \\
\hline Body mass index $\left(\mathrm{kg} / \mathrm{m}^{2}\right)$ & $1.69(0.89-2.49)$ & $<0.001$ \\
\hline Cirrhosis & $4.03(0.32-7.74)$ & 0.033 \\
\hline Diabetes & $-2.57(-7.01-1.87)$ & 0.26 \\
\hline \multicolumn{3}{|l|}{ Previous NA regimen } \\
\hline ETV monotherapy & Reference & \\
\hline TDF monotherapy & $-3.09(-8.01-1.84)$ & 0.22 \\
\hline \multirow[t]{2}{*}{ NA combination } & $-1.24(-6.07-3.60)$ & 0.62 \\
\hline & qHBsAg & \\
\hline Characteristics & Coefficient $(95 \% \mathrm{Cl})$ & P-value \\
\hline Age (year) & $-7.75(-14.3--1.24)$ & 0.020 \\
\hline Male & $-55.1(-297-187)$ & 0.66 \\
\hline Cirrhosis & $-9.70(-130-111)$ & 0.88 \\
\hline Baseline HBeAg-positive & $-109(-532-315)$ & 0.61 \\
\hline Baseline $\mathrm{qHBsAg}$ & $0.81(0.74-0.88)$ & $<0.001$ \\
\hline \multicolumn{3}{|l|}{ Previous NA regimen } \\
\hline ETV monotherapy & Reference & \\
\hline TDF monotherapy & $27.4(-259-314)$ & 0.85 \\
\hline \multirow[t]{2}{*}{ NA combination } & $150(-98.5-399)$ & 0.24 \\
\hline & eGFR & \\
\hline Characteristics & Coefficient $(95 \% \mathrm{Cl})$ & P-value \\
\hline Age (year) & $-0.48(-0.60--0.36)$ & $<0.001$ \\
\hline
\end{tabular}

ALT, alanine aminotransferase; qHBsAg, quantitative hepatitis B surface antigen; eGFR, estimated glomerular filtration rate; $\mathrm{Cl}$, confidence interval; NA, nucleos(t)ide analog; ETV, entecavir; TDF, tenofovir disoproxil fumarate; HBeAg, hepatitis B e antigen; HBsAg, hepatitis B surface antigen. 


\begin{tabular}{|c|c|c|}
\hline & ALT & \\
\hline Male & $-0.41(-3.04-2.21)$ & 0.76 \\
\hline Body mass index $\left(\mathrm{kg} / \mathrm{m}^{2}\right)$ & $-0.10(-0.56-0.36)$ & 0.67 \\
\hline Cirrhosis & $-0.71(-3.65-2.22)$ & 0.63 \\
\hline Diabetes & $2.14(-2.23-6.51)$ & 0.34 \\
\hline Hypertension & $2.11(-1.24-5.45)$ & 0.22 \\
\hline \multicolumn{3}{|c|}{ Baseline eGFR $\left(\mathrm{mL} / \mathrm{min} / 1.73 \mathrm{~m}^{2}\right)$} \\
\hline$\geq 60$ & Reference & \\
\hline$<60$ & $21.7(19.2-24.1)$ & $<0.001$ \\
\hline \multicolumn{3}{|l|}{ Previous NA regimen } \\
\hline ETV monotherapy & Reference & \\
\hline TDF/ADF included & $-0.06(-2.57-2.45)$ & 0.96 \\
\hline \multicolumn{3}{|c|}{$\begin{array}{l}\text { ALT, alanine aminotransferase; qHBsAg, quantitative hepatitis B surface antigen; eGFR, estimated } \\
\text { glomerular filtration rate; } \mathrm{Cl} \text {, confidence interval; } \mathrm{NA} \text {, nucleos }(\mathrm{t}) \text { ide analog; } \mathrm{ETV} \text {, entecavir; TDF, } \\
\text { tenofovir disoproxil fumarate; HBeAg, hepatitis B e antigen; HBsAg, hepatitis B surface antigen. }\end{array}$} \\
\hline
\end{tabular}

\section{Discussion}

In our previous cohort study, we showed the virological effectiveness and the renal safety 48 weeks after switching to TAF [17]. We noted that the durability of the results would need confirmation in longer term analysis. The present study done post- 96 weeks confirmed the previous findings and clarified the longterm effects of switching to TAF.

We divided patients into three groups according to the prior NA regimen (ETV, TDF, or NA combination). Almost all had achieved HBV DNA suppression by week 96 post switchover, even those treated with an NA combination. Moreover, the prior NA regimen had little influence on the longitudinal changes of ALT, qHBsAg level, or eGFR. We believe that our study provides important insights into the effectiveness of a switch to TAF for patients with CHB who had been treated with older NAs.

Virological efficacy, including HBV DNA suppression and a decrease of the qHBsAg level, has contributed to a decline of the HCC incidence rate [20-22]. In our prior ETV group, $91.3 \%$ of the patients who had detectable HBV DNA at baseline achieved HBV DNA suppression at week 48, as did 95.7\% at week 96 . Similar findings were seen in the prior TDF and NA combination groups. These incremental improvements following switching to TAF were significant, even though our patients had already received NA treatment for an average duration of more than seven years. It is noteworthy that none of the patients under controlled virological condition by a prior NA regimen experienced viral breakthrough during the 96 
weeks after switchover. In contrast, virological response with HBeAg loss was not adequately achieved at week 96. For those with a low-titer of $\mathrm{HBeAg}(<10 \mathrm{~S} / \mathrm{CO})$ at baseline, fewer than half experienced $\mathrm{HBeAg}$ loss. The rate of HBsAg loss remained very low (approximately $1 \%$ annually), and the decline in the qHBsAg levels were small (approximately $0.1 \mathrm{log} \mathrm{IU} / \mathrm{mL}$ annually). Nevertheless, a lower qHBsAg level at baseline was significantly associated with a decreased qHBsAg level.

Consistent with our previous study of 48 weeks [17], we did not observe significant positive changes in the rates of ALT normalization at 96 weeks after switching to TAF. More patients in the prior TDF group who had an elevated ALT level at baseline achieved ALT normalization when using the normal range proposed by AASLD, similar to a recent report [23]; however, as we noted, those who had higher BMI and cirrhosis were less likely to have an improvement in the ALT level at 96 weeks after adjustment for confounding factors. The evaluation of non-alcoholic fatty liver disease and steatohepatitis will be important in the monitoring of patients with elevated ALT levels.

The high prevalence of renal dysfunction highlights the long-term need for careful monitoring or switching to TAF from ADF or TDF treatment, as is recommended in the guidelines [3, 4]. Phase 3 clinical trials, in which virologically suppressed CHB patients were switched from TDF to TAF, showed improvements in kidney parameters at week 96 after switching [23]. One of the strengths of this study was the inclusion of patients with prior ETV or NA combination therapy, all of whom were treated with TAF for at least 96 weeks. In our multivariable GEE analysis that controlled cofounding factors with kidney function, patients of older age and without CKD were less likely to experience positive changes in eGFR. There was no statistically significant trend in eGFR over time for patients with without CKD: the decrement was approximately $1 \mathrm{~mL} / \mathrm{min} / 1.73 \mathrm{~m}^{2}$ per year, which is considered to be physiological reduction. Instead, the improvement in eGFR for those with CKD should be emphasized because the decline in eGFR was consistently more in those with lower baseline eGFR. It is also important to note that the incremental improvements following switching to TAF peeked between 24 and 48 weeks then decreased physiologically, but without a statistically significant trend.

Data on the 96 weeks after TAF switchover is currently lacking, so longer-term follow-up will be needed to fully characterize the virological and safety profiles. In addition to the fact that our patients had been previously treated with ETV or an NA combination, the strengths of this study are that it included many elderly (65 and over: $n=167$ ) and CKD patients $(n=114)$, which empowers our interpretation. Moreover, we used GEE modeling, which controls for collinearity across variables, allows a bigger sample size to be examined, and makes it possible to better evaluate the related factors for improvements of ALT, qHBsAg level, and eGFR.

This study has several limitations. First, control with a continuing NA groups and data on bone mineral density are lacking, as we mentioned previously. These data will be necessary to better determine differences in clinical outcomes in future study. However, we have provided the data of 458 patients who have been treated with TAF for 96 weeks; to our knowledge, this is the largest real-world study of sequential treatment with TAF. Second, learning the background of or reasons for the switch to TAF for

Page $15 / 23$ 
each patient would be useful to more deeply understand the outcomes: another report suggested that patients who were switched to TAF had better adherence [25]. Last, we have not shown data on the NA drug resistance profile, including LMV, ADF, and ETV. Detailed information regarding the resistance profile would be helpful for the monitoring of intractable cases.

In summary, switching the drug used in HBV treatment to TAF was effective for HBV suppression and continued qHBsAg reduction at 96 weeks. The proportion of complete response reached a plateau at 48 weeks, irrespective of previous NA regimen. Patients with CKD who were previously treated with TDF or an NA combination had a favorable outcome with an improvement of eGFR within one year of switchover that was maintained over the 96 weeks of study.

\section{Abbreviations}

$\mathrm{CHB}$, chronic hepatitis B; HCC, hepatocellular carcinoma; NA, nucleos(t)ide analog; ETV, entecavir; TDF, tenofovir disoproxil fumarate; TAF, tenofovir alafenamide; HBsAg, hepatitis B surface antigen; HBV, hepatitis B virus; HIV, human immunodeficiency virus; BMD, bone mineral density; qHBsAg, quantitative hepatitis $B$ surface antigen; eGFR, estimated glomerular filtration rate; CKD, chronic kidney disease; LAM, lamivudine; ADF, adefovir; ALT, alanine aminotransferase; AASLD, American Association for the Study of Liver Diseases; GEE, generalized estimating equation; $\mathrm{BMI}$, body mass index; $\mathrm{Cl}$, confidence interval; $\mathrm{HBeAg}$, hepatitis B e antigen.

\section{Declarations}

\section{Author contributions:}

All authors were involved in the design of the study, acquisition of samples and/or analysis. EO drafted the manuscript. All authors contributed to the critical discussion of the results and approved the final version of the article.

\section{Conflicts of interest:}

EO has received speaker fees from Gilead Sciences and AbbVie. The other authors declare that they have no conflicts of interest.

\section{Funding:}

This study was funded by Gilead Sciences.

\section{References}

[1] Lozano R, Naghavi M, Foreman K, Lim S, Shibuya K, Aboyans V, et al. Global and regional mortality from 235 causes of death for 20 age groups in 1990 and 2010: a systematic analysis for the Global Burden of Disease Study 2010. Lancet 2012; 380: 2095-2128. 
[2] Schweitzer A, Horn J, Mikolajczyk RT, Krause G, Ott JJ. Estimations of worldwide prevalence of chronic hepatitis B virus infection: a systematic review of data published between 1965 and 2013. Lancet 2015; 386: 1546-1555.

[3] Terrault NA, Lok ASF, McMahon BJ, et al. Update on prevention, diagnosis, and treatment of chronic hepatitis B: AASLD 2018 hepatitis B guidance. Hepatology 2018; 67: 1560-1599.

[4] European Association for the Study of the Liver. EASL 2017 Clinical Practice Guidelines on the management of hepatitis B virus infection. J Hepatol 2017; 67: 370-398.

[5] Sarin SK, Kumar M, Lau GK, Abbas Z, Chan HL, Chen CJ, et al. Asian-Pacific clinical practice guidelines on the management of hepatitis B: a 2015 update. Hepatol Int 2016; 10: 1-98.

[6] Lok AS, Zoulim F, Dusheiko G, Ghany MG. Hepatitis B cure: From discovery to regulatory approval. J Hepatol 2017; 67: 847-861.

[7] Cornberg M, Lok AS, Terrault NA, Zoulim F; 2019 EASL-AASLD HBV Treatment Endpoints Conference Faculty. Guidance for design and endpoints of clinical trials in chronic hepatitis B - Report from the 2019 EASL-AASLD HBV Treatment Endpoints Conference ${ }^{\ddagger}$. J Hepatol 2020; 72: 539-557.

[8] Ogawa E, Furusyo N, Nguyen MH. Tenofovir alafenamide in the treatment of chronic hepatitis B: design, development, and place in therapy. Drug Des Devel Ther 2017; 11: 3197-3204.

[9] Lok AS, McMahon BJ, Brown RS Jr, Wong JB, Ahmed AT, Farah W, Almasri J, Alahdab F, Benkhadra K, Mouchli MA, Singh S, Mohamed EA, Abu Dabrh AM, Prokop LJ, Wang Z, Murad MH, Mohammed K. Antiviral therapy for chronic hepatitis $B$ viral infection in adults: A systematic review and meta-analysis. Hepatology 2016; 63: 284-306.

[10] Woo G, Tomlinson G, Nishikawa Y, Kowgier M, Sherman M, Wong DK, Pham B, Ungar WJ, Einarson TR, Heathcote EJ, Krahn M. Tenofovir and entecavir are the most effective antiviral agents for chronic hepatitis B: a systematic review and Bayesian meta-analyses. Gastroenterology 2010; 139: 1218-1229.

[11] Tang LSY, Covert E, Wilson E, Kottilil S. Chronic Hepatitis B Infection: A Review. JAMA 2018; 319: 1802-1813.

[12] Casado JL. Renal and Bone Toxicity with the Use of Tenofovir: Understanding at the End. AIDS Rev 2016; 18: 59-68.

[13] Buti M, Tsai N, Petersen J, Flisiak R, Gurel S, Krastev Z, Aguilar Schall R, Flaherty JF, Martins EB, Charuworn P, Kitrinos KM, Subramanian GM, Gane E, Marcellin P. Seven-year efficacy and safety of treatment with tenofovir disoproxil fumarate for chronic hepatitis B virus infection. Dig Dis Sci 2015; 60: 1457-1464. 
[14] Chan HL, Fung S, Seto WK, et al. Tenofovir alafenamide versus tenofovir disoproxil fumarate for the treatment of HBeAg-positive chronic hepatitis B virus infection: a randomised, double-blind, phase 3, noninferiority trial. Lancet Gastroenterol Hepatol 2016; 1: 185-195.

[15] Buti M, Gane E, Seto WK, et al. Tenofovir alafenamide versus tenofovir disoproxil fumarate for the treatment of patients with $\mathrm{HBeAg-negative} \mathrm{chronic} \mathrm{hepatitis} \mathrm{B} \mathrm{virus} \mathrm{infection:} \mathrm{a} \mathrm{randomised,} \mathrm{double-blind,}$ phase 3, non-inferiority trial. Lancet Gastroenterol Hepatol 2016; 1: 196-206.

[16] Agarwal K, Brunetto $M$, Seto WK, et al. 96 weeks treatment of tenofovir alafenamide vs. tenofovir disoproxil fumarate for hepatitis B virus infection. J Hepatol 2018; 68: 672-681.

[17] Ogawa E, Nomura H, Nakamuta M, Furusyo N, Koyanagi T, Dohmen K, Ooho A, Satoh T, Kawano A, Kajiwara E, Takahashi K, Azuma K, Kato M, Shimoda S, Hayashi J. Tenofovir alafenamide after switching from entecavir or nucleos(t)ide combination therapy for patients with chronic hepatitis B. Liver Int 2020; 40: 1578-1589.

[18] Matsuo S, Imai E, Horio M, et al. Revised equations for estimated GFR from serum creatinine in Japan. Am J Kidney Dis 2009; 53: 982-992.

[19] Ogawa E, Furusyo N, Murata M, et al. Longitudinal assessment of liver stiffness by transient elastography for chronic hepatitis B patients treated with nucleoside analog. Hepatol Res $2011 ; 41$ : 11781188.

[20] Wong GL, Chan HL, Mak CW, Lee SK, Ip ZM, Lam AT, lu HW, Leung JM, Lai JW, Lo AO, Chan HY, Wong VW. Entecavir treatment reduces hepatic events and deaths in chronic hepatitis $B$ patients with liver cirrhosis. Hepatology 2013; 58: 1537-1547.

[21] Tseng TC, Liu CJ, Yang HC, Su TH, Wang CC, Chen CL, Kuo SF, Liu CH, Chen PJ, Chen DS, Kao JH. High levels of hepatitis B surface antigen increase risk of hepatocellular carcinoma in patients with low HBV load. Gastroenterology 2012; 142: 1140-1149.

[22] Yip TC, Wong GL, Chan HL, Tse YK, Lam KL, Lui GC, Wong VW. HBsAg seroclearance further reduces hepatocellular carcinoma risk after complete viral suppression with nucleos(t)ide analogues. J Hepatol 2019; 70: 361-370.

[23] Chan HLY, Buti M, Agarwal K, et al. Maintenance of high levels of viral suppression and improved safety profile of tenofovir alafenamide relative to tenofovir disoproxil fumarate in chronic hepatitis $B$ patients treated for 5 years in 2 ongoing phase 3 studies. Hepatology 2020; 72: 490A.

[24] Coresh J, Turin TC, Matsushita K, Sang Y, Ballew SH, Appel LJ, Arima H, Chadban SJ, Cirillo M, Djurdjev O, Green JA, Heine GH, Inker LA, Irie F, Ishani A, Ix JH, Kovesdy CP, Marks A, Ohkubo T, Shalev V, Shankar A, Wen CP, de Jong PE, Iseki K, Stengel B, Gansevoort RT, Levey AS. Decline in estimated 
glomerular filtration rate and subsequent risk of end-stage renal disease and mortality. JAMA 2014; 311: 2518-2531.

[25] Tamaki N, Kurosaki M, Nakanishi H, Itakura J, Inada K, Kirino S, Yamashita K, Osawa L, Sekiguchi S, Hayakawa Y, Wang W, Okada M, Higuchi M, Takaura K, Maeyashiki C, Kaneko S, Yasui Y, Tsuchiya K, Takahashi Y, Izumi N. Comparison of medication adherence and satisfaction between entecavir and tenofovir alafenamide therapy in chronic hepatitis B. J Med Virol 2020; 92: 1355-1358.

\section{Figures}


Figure 1

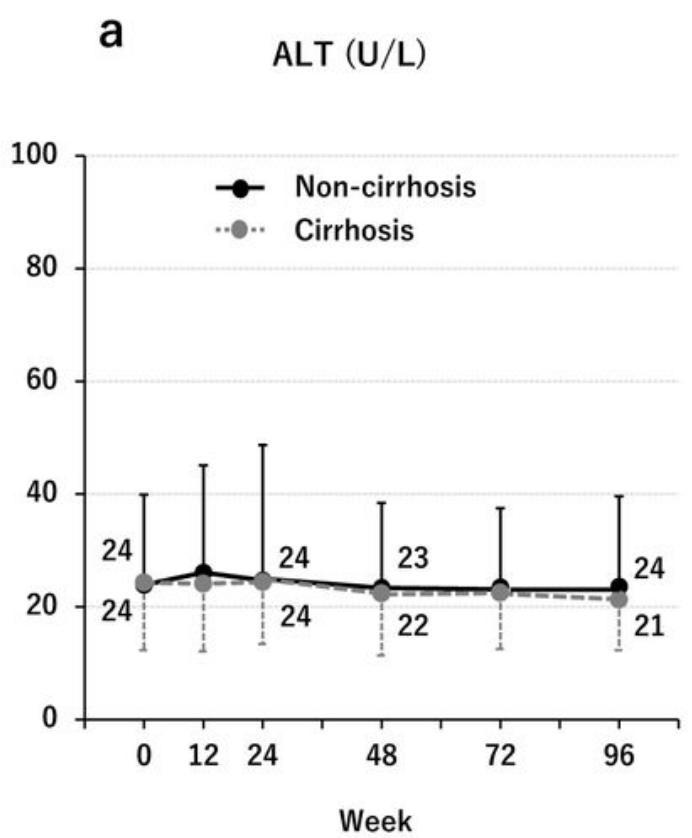

b $\quad \mathrm{HBsAg}(\log \mathrm{IU} / \mathrm{mL})$

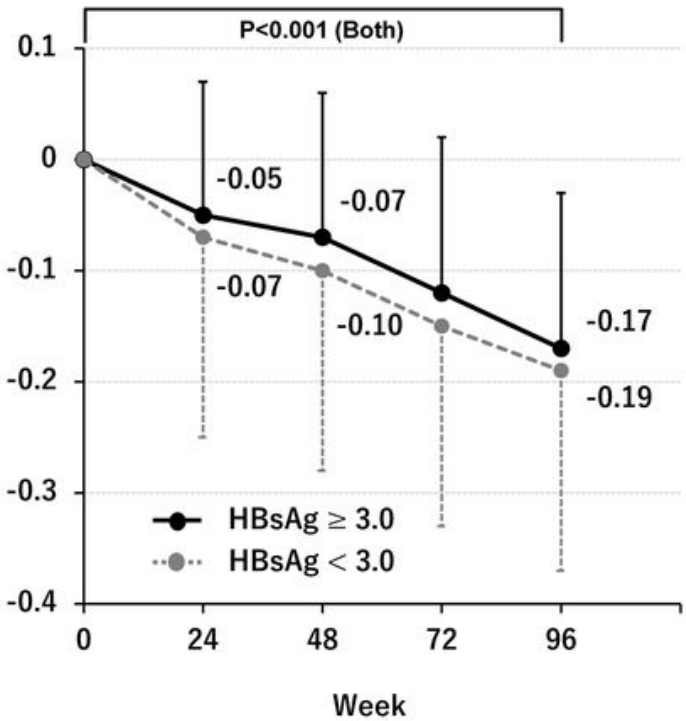

Switch from ETV to TAF

C $\quad$ eGFR $\left(\mathrm{mL} / \mathrm{min} / 1.73 \mathrm{~m}^{2}\right)$

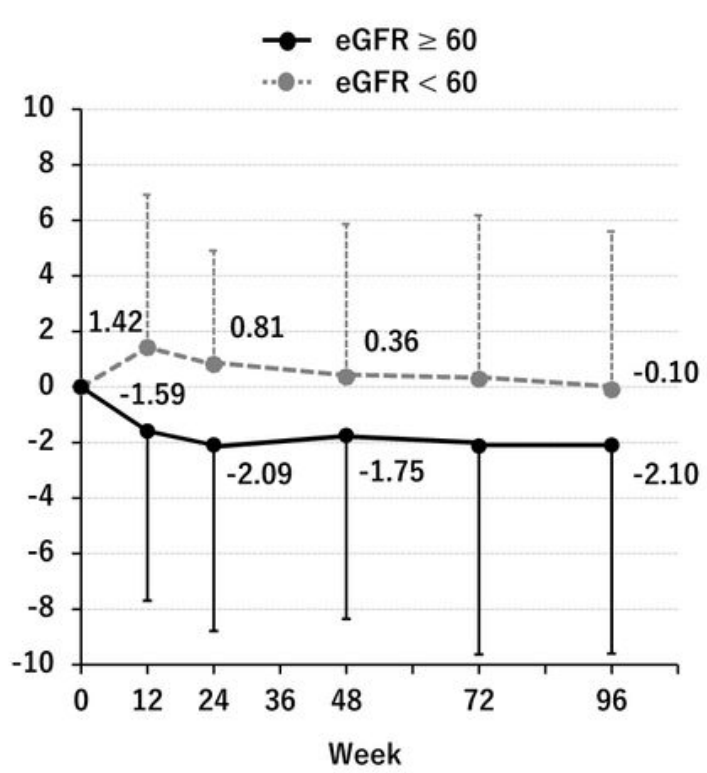

d Phosphorus $(\mathrm{mg} / \mathrm{dL})$

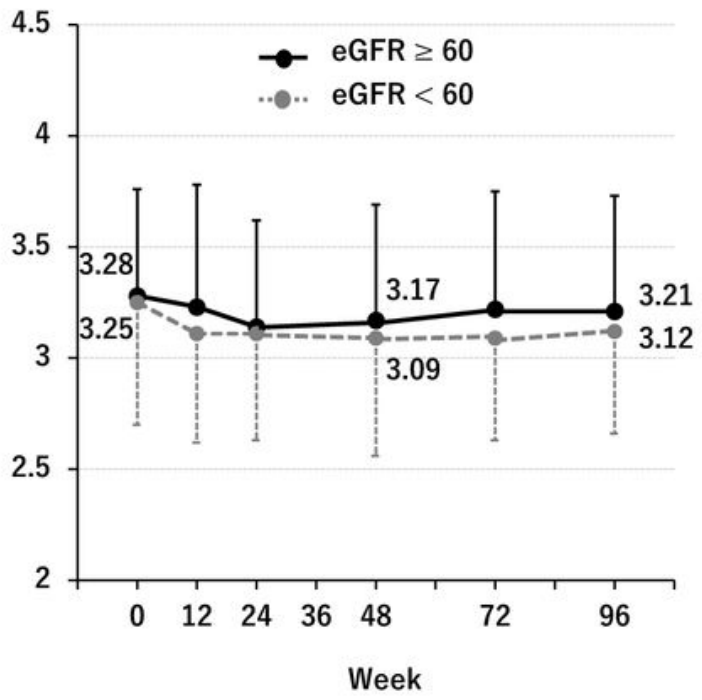

\section{Figure 1}

Longitudinal change in (a) ALT, (b) qHBsAg level, (c) eGFR, and (d) serum phosphorus level from baseline to 96 weeks after switching from ETV to TAF. Bars are expressed as mean \pm standard deviation. ALT, alanine aminotransferase; qHBsAg, quantitative hepatitis B surface antigen; eGFR, estimated glomerular filtration rate; ETV, entecavir; TAF, tenofovir alafenamide. 
Figure 2

a

$\operatorname{ALT}(\mathrm{U} / \mathrm{L})$

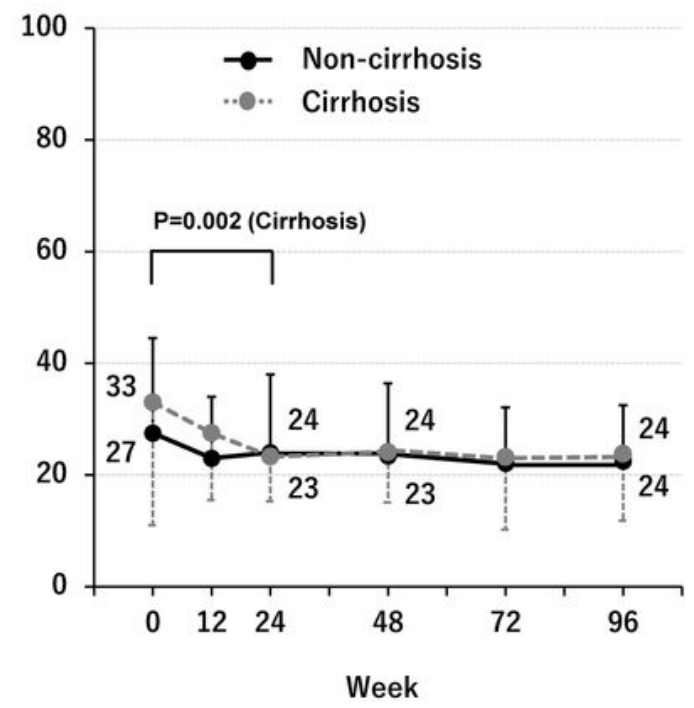

Switch from TDF to TAF

b HBsAg $(\log I \mathrm{U} / \mathrm{mL})$

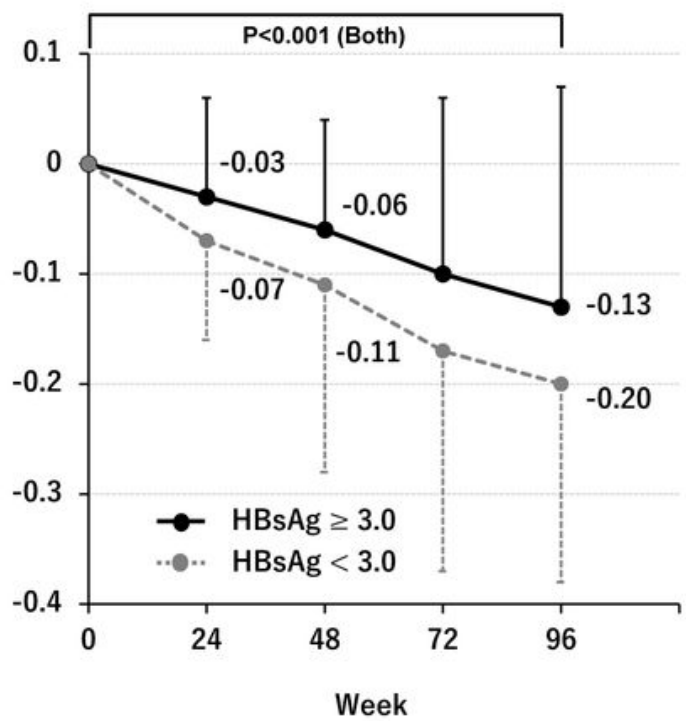

Switch from TDF to TAF

C eGFR $\left(\mathrm{mL} / \mathrm{min} / 1.73 \mathrm{~m}^{2}\right)$

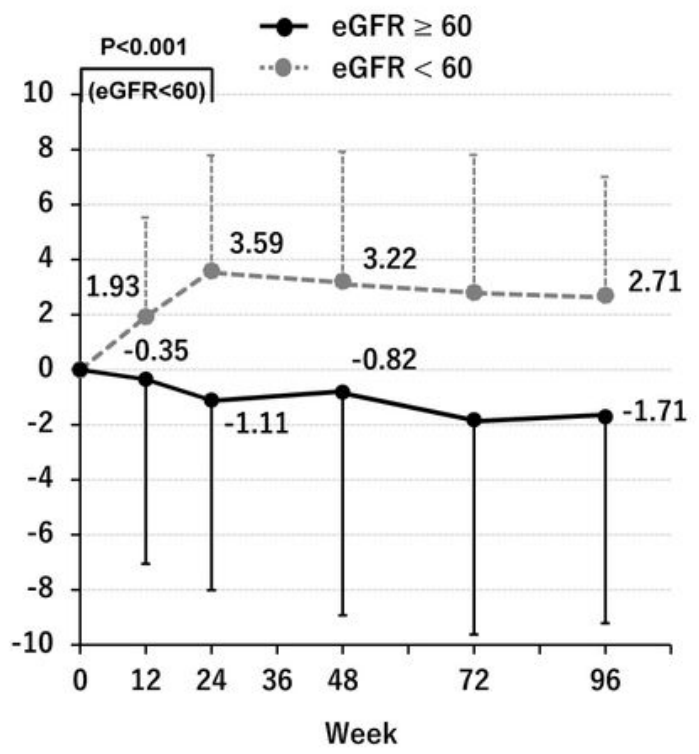

d Phosphorus (mg/dL)

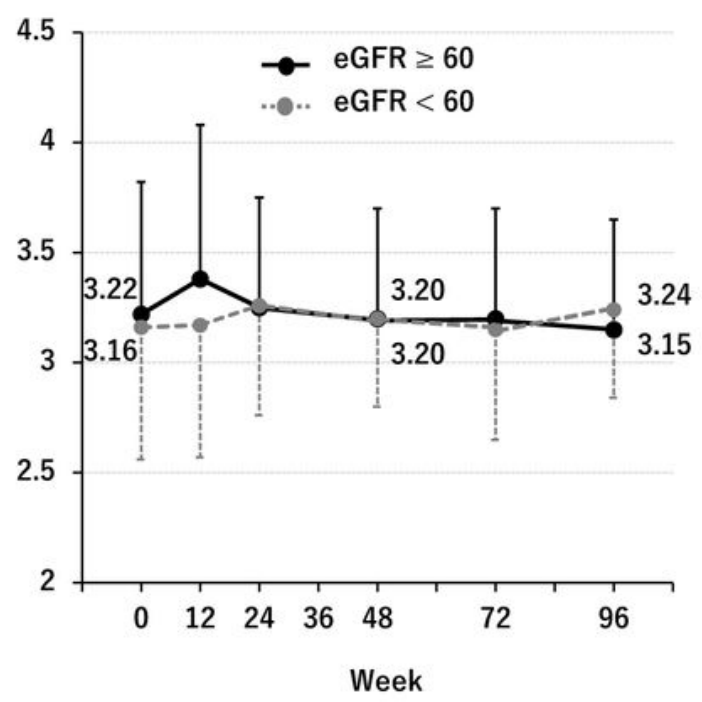

\section{Figure 2}

Longitudinal change in (a) ALT, (b) qHBsAg level, (c) eGFR, and (d) serum phosphorus level from baseline to 96 weeks after switching from TDF to TAF. Bars are expressed as mean \pm standard deviation. ALT, alanine aminotransferase; qHBsAg, quantitative hepatitis B surface antigen; eGFR, estimated glomerular filtration rate; TDF, tenofovir disoproxil fumarate; TAF, tenofovir alafenamide. 
Figure 3

a

$\operatorname{ALT}(\mathrm{U} / \mathrm{L})$

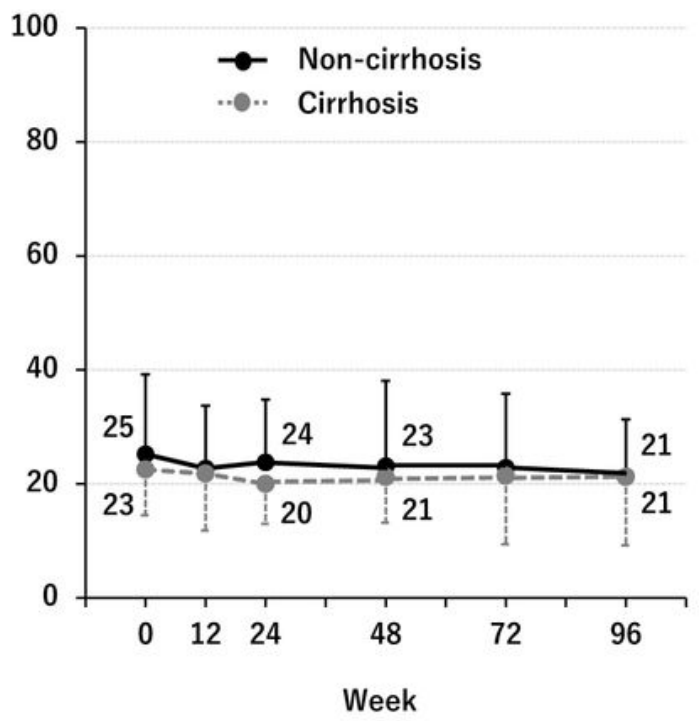

Switch from NA combination to TAF

b $\quad \mathrm{HBsAg}(\log I \mathrm{U} / \mathrm{mL})$

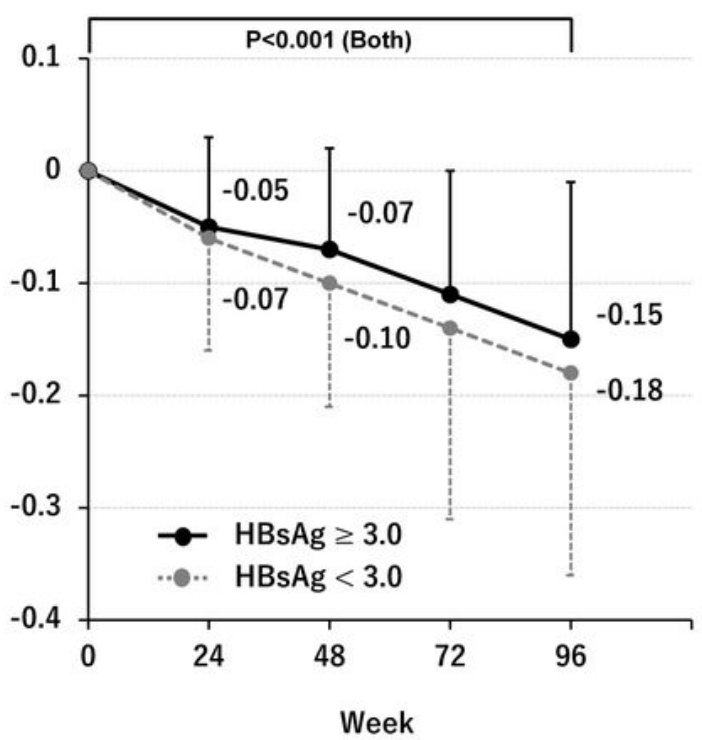

Switch from NA combination to TAF

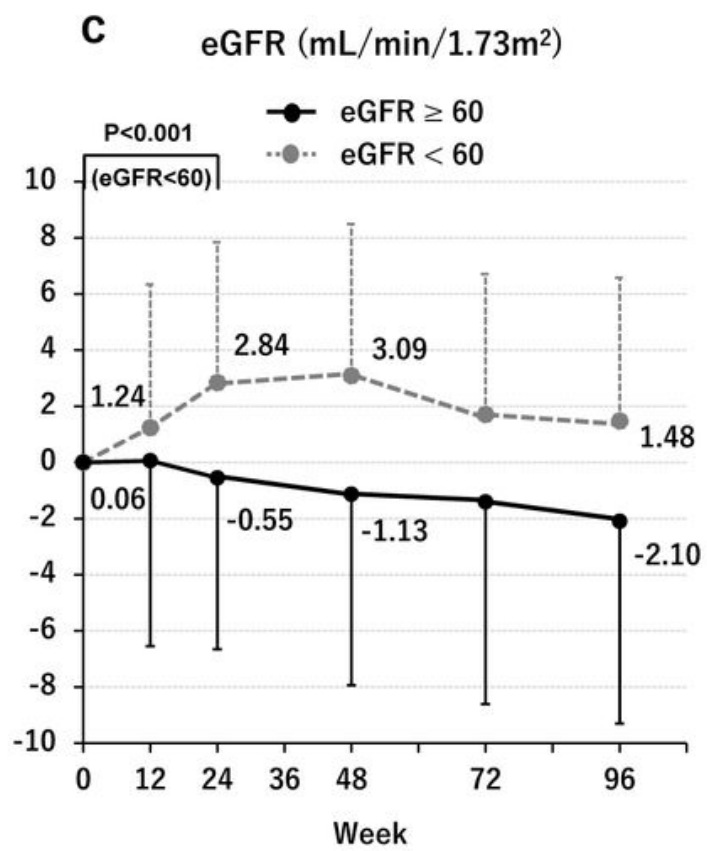

d Phosphorus $(\mathrm{mg} / \mathrm{dL})$

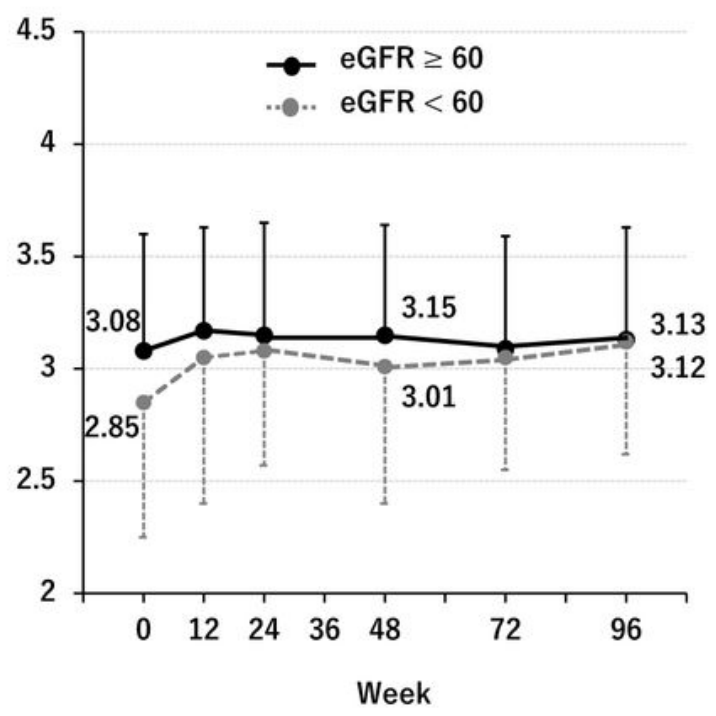

\section{Figure 3}

Longitudinal change in (a) ALT, (b) qHBsAg level, (c) eGFR, and (d) serum phosphorus level from baseline to 96 weeks after switching from NA combination to TAF. Bars are expressed as mean \pm standard deviation. ALT, alanine aminotransferase; qHBsAg, quantitative hepatitis B surface antigen; eGFR, estimated glomerular filtration rate; $\mathrm{NA}$, nucleos(t)ide analog; TAF, tenofovir alafenamide. 


\section{Supplementary Files}

This is a list of supplementary files associated with this preprint. Click to download.

- KULDSHBVTAFswitch96wSuppleTableHepatInt.docx 